\title{
Regional Rural Banks and Rural Development: A Case of Pragathi Krishna Gramin Bank
}

Volume: 7

Issue: 2

Month: March

Year: 2019

ISSN: 2319-961X

Received: 9.3.2019

Accepted: 11.3.2019

Published: 15.3.2019

Citation:

Tigari, Harish, and M. G. Gaganadeepa. "Regional Rural Banks and Rural Development: A Case of Pragathi Krishna Gramin Bank." Shanlax International Journal of Economics, vol. 7 no. 2, 2019, pp. 68-74.

DOI:

https://doi.org/10.34293/ economics.v7i2.315

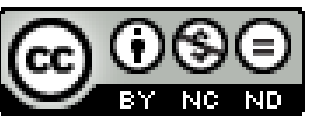

This work is licensed under a Creative Commons Attribution-NonCommercialNoDerivatives 4.0 International License

\author{
Harish Tigari \\ Faculty Member, Department of Commerce \\ Davangere University, Shivagangotri, Karnataka, India
}

\section{M.G.Gaganadeepa}

$P G$ Student, Department of Commerce

Davangere University, Shivagangotri, Karnataka, India

\begin{abstract}
The rural banking is one of the important roles in rural development of our country, and the village economy is the backbone of the Indian economy. Without the development of the rural economy, the objective of economic planning cannot be achieved. Hence the Regional rural banks (RRBs) are plays a vital role in the rural development for the economy in India. The RRBs were established on October 2, 1975, with the main objective of a provisional credit to rural people who are not economically strong enough, especially the small farmers, artisans, agricultural laborers, and even small entrepreneurs. The present study is a modest attempt to rural credit structure and the role played by RRBs in the development of rural economy. The present research paper is designed in nature and makes use of secondary data. The relevant secondary data have been collected mainly through the articles, journals, books, and websites have been referred. This paper is to examine the rural credit structure in RRBs of Pragathi Krishna Gramin Bank. And this study is focused only on the specific area like loans and advances made by the RRBs for three years period of 2015-16 to the year 2017-18.
\end{abstract}

Keywords: Rural Development, Regional Rural Banks, Rural economy, Agriculture

\section{Introduction}

Rural development has to play a predominant role in the overall socioeconomic development of developing economies like India, where the majority of the population lives in rural areas. Rural Development refers to the process of improving the living conditions of rural people. Rural people also face the risk of unanticipated production of crops due to high dependency on monsoon. With the problem of finance, they also suffer from lack of seeds, fertilizers, water supply, and other facilities which rural in deftness. Rural development is a process deals with improving the standard of living of the people living in rural areas. it may be defined as the overall socio-economic development of rural areas to improve the quality of life of rural people. It is an integrative approach, which includes social, economic, political and spiritual development of the poorer sections of the society. In an agricultural economy, Rural Development is one of the most important key factors for the growth of the economy. India is primarily an agriculture-based country. The Agricultural contribution is nearly amounting to one-fifth of the gross domestic product in India, Rural Development in India is the apex body for formulating policies, regulations and acts pertaining to the development of the rural sector. 
Agriculture, handicrafts, poultry, fisheries, and dairy are the primary contributors to the rural business and economy. Regional rural banks are gross root level banking organizations operating in different states of India. They have been created with an objective to serve the rural areas of India with basic banking and financial services.

\section{Review of Literature}

Dr. Manohar Kacharu Sanapwas discuss the role and responsibilities of Rural banks in rural development of different areas like agricultural, trade, Entrepreneurship and self-employment and the other productive activities in the rural areas. In the rural bank facilities, the financial services through the loans of different areas and rural banks as a mobilize the savings of the rural people. Biswa Swarup Mishra as mentioned on the performance of regional rural banks in India, the rural bank have taken deep roots and made rural credit structure in India and regional rural bank as corporate with their rural focus of commercial activities in the rural area. N Subitha Devi (April 2014) was addressed the regional rural banks role in the agricultural and rural development in India, and facing the problems of overdue, recovery and non-performing Assets and other problems. Rural banks are established to mobilize the rural area small Savings and providing banking facilities to small and backward areas. Mr. Kedar V. Marulkar discussed the role of Banking in the rural industrialization of Rural Development, the bank has been playing the prominent role in industrialization in general, but when comes to an industrialization in rural area cannot say with the confidence that Bank successfully achieving an objective of the rural development through the industrialization..

\section{Objective of the Study}

- To study of the rural development and its importance in India.

- $\quad$ To discuss the role of Regional Rural Banks in rural development..

\section{Research Methodology}

Primary data: Primary data is looking into requirement from the resource of collection from the bank employees, and beneficial of the banks in design the descriptive type of research.

Secondary data: This research paper as an attempt to exploratory research, on the, based on secondary data sources from the previous research papers, articles, government reports, magazines, published books. Available secondary data was extensively used for the research.

\section{Problematization}

The major problem of Regional Rural Banks in rural development is the most rural people are illiterate people so they don't know how to get financial facilities from RRB. And the lack of communication between rural people and bank employees of Regional Rural Bank. And sometimes interfere with the middlemen's between bank and beneficiaries. And these banks have still not played a significant role in poverty alleviation of the country. The efforts have been made to achieve in this regard but lack of economic infrastructure, poor marketing strategies, poor knowledge of customers, low production, low awareness about savings have created many hurdles of RRB.

\section{Scope of the Study}

Majority of Regional Rural Banks are covered Limited rural areas are particular geographical areas of priority of development-oriented, and it provides the facilities of this area only, so I take for the study to rural areas which are coming in under the Regional Rural Bank of Pragathi Krishna Grameena Bank, Chikkabennuru branch and some villages covered under bank circle.

\section{Limitations of the Study}

- $\quad$ The present study restricted to Chikkabennur village only.

- The sample size is small, due to budget and time.

\section{Need for the Study}

This study has very essential need for understand the roles and responsibilities of regional rural banks in rural development, and analysis the growth of rural development to different areas and to promote a rural people, and gain the knowledge of banking system 
and promote the development through economic activities, And the analyze the performance of regional rural bank in the rural development.

\section{Conceptual Framework}

\section{Regional Rural Banks in India}

In India, RRBs were established on October, 2nd 1975. The main objectives of RRBs are to provide financial credit and other facilities particularly to very small and marginal farmers, wage-based agricultural laborers', rural artisans and small entrepreneurs so as to develop agricultural activities, trade and commerce, rural industrialization and other productive activities in rural areas. The main purpose of RRB's is to mobilize financial resources from rural or semi-urban areas and grant loans advances mostly to small and marginal farmers, agricultural laborers and rural artisans. The area of operation of Regional Rural Banks is limited to the area as notified by Government of India covering one or more districts in the State. The RRBs were owned by the Central Government, the State Government and the Sponsor Bank (Any commercial bank can sponsor the regional rural banks) who held shares in the ratios as follows Central Government-50\%, State Government-15\% and Sponsor Banks - 35\%. The role of the RRBs cannot be ignored in present day banking system as the Gramina Bank have played a major role in the implementation of central and state government sponsored various programs of poverty alleviation like SGSRY, PMGAY, JGSY. Scholarships to students, Payment to Anganwadi, Old age Pension, Scholarships to students, Indira
Awas Yojana, Laborer payment to MGNREGA beneficiary has effectively been carried by these RRBs.

\section{Rural Development}

The perspective of development with rural area acronym as rural development is the process of improving the standard of living with quality of life and economic well-being of people resided in rural areas are often relatively isolated and sparsely populated areas. The concept of rural development as enunciated by the World Bank, marks such as a change, the World Bank defense the rural development strategy designed to improve the economic and social life of the specific group of a people- the rural poor. It involves extending the benefits of the development of the poorest among those who livelihood in rural areas. The group includes small scale farmers, tenants, and the landless. There are no universally accepted approaches to rural development, means it is a choice influenced by time, space and culture. The term rural development connotatively deals with the overall development of rural areas to improve the quality of life of rural people. In the sense, rural development is a comprehensive and multidimensional concept and encompasses the development of agriculture and allied activities, village and cottage industries and crafts, socio-economic infrastructure, community services and facilities and, above all, human resources in rural areas.

\section{Data Analysis and Interpretation}

Table: Mobilization Fund, Loans and Advances of Pragathi Krishna Gramina Bank

\begin{tabular}{|c|l|c|c|c|c|c|c|}
\hline \multirow{2}{*}{ S.No. } & \multirow{2}{*}{ Sectors } & \multicolumn{2}{|c|}{$\mathbf{2 0 1 5}-\mathbf{2 0 1 6}$} & \multicolumn{2}{c|}{$\mathbf{2 0 1 6 - 2 0 1 7}$} & \multicolumn{2}{c|}{ 2017-2018 } \\
\cline { 3 - 8 } & & A/c's & Amount & A/c's & Amount & A/c's & Amount \\
\hline 1 & Mobilization Fund & 37 & $40,47,000$ & 72 & $39,06,000$ & 76 & $40,40,000$ \\
\hline 2 & Agricultural Loan & 06 & $15,00,000$ & 37 & $42,00,000$ & 15 & $21,00,000$ \\
\hline 3 & Development Loan & 03 & & 01 & $3,50,000$ & 01 & $4,00,000$ \\
\hline 4 & Gold Loan & 31 & $10,90,000$ & 30 & $12,10,000$ & 36 & $15,60,000$ \\
\hline 5 & Education Loan & 02 & $3,60,000$ & - & - & 02 & $2,87,000$ \\
\hline 6 & Self Help Group & 01 & $4,00,000$ & - & - & 04 & $7,20,000$ \\
\hline & Total & $\mathbf{8 0}$ & $\mathbf{7 5 , 0 7 , 0 0 0}$ & $\mathbf{1 4 0}$ & $\mathbf{9 6 , 6 6 , 0 0 0}$ & $\mathbf{1 3 4}$ & $\mathbf{9 1 , 0 7 , 0 0 0}$ \\
\hline
\end{tabular}

Source: Field Survey 


\section{Graph 1}

Mobilization Fund, Loans and Advances of Pragathi Krishna Gramina Bank

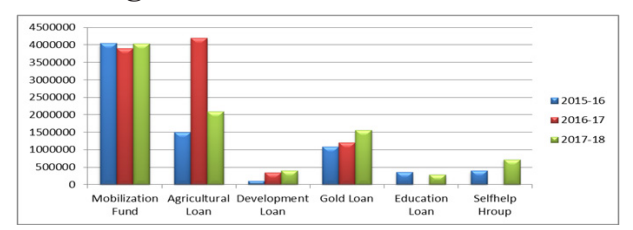

The analysis of Pragathi Krishna Gramin Bank, chikkabennur is having an area of 6 postal geographical areas, providing financial loans and advances for the rural development activities in different sectors, the data of loan and advances of collected only 3 years data of 2015-16, 2016-17, 2017-18, respectively. The collection of mobilization fund in Gramina bank was the year of the 2015-16 financial year from $37 \mathrm{~A} / \mathrm{c}$ holders of 40,47,000Rs. In 2016-17 financial year was collected from 72 $\mathrm{A} / \mathrm{c}$ holders of $39,06,000 \mathrm{Rs}$. And the 2017-18 financial year was the collected from $76 \mathrm{~A} / \mathrm{c}$ holders of 40,40,000Rs. In three years data of the highest mobilization fund is collected in the year of 201516 as highest margin fund. Agricultural Sectors is the most important sector in rural development, the majority of the people depend on agriculture in rural areas. In the agriculture activities, rural bank provided loans in the 2015-16 financial year of to $6 \mathrm{~A} / \mathrm{c}$ holders to $15,00,000 \mathrm{Rs}$. In the financial year 2016-17 of $37 \mathrm{~A} / \mathrm{c}$ holders to $42,00,000 \mathrm{Rs}$. And in the financial year of $2017-18$ has provided to 15 $\mathrm{A} / \mathrm{c}$ holders to $21,00,000 \mathrm{Rs}$. In the three years of the 2016-17 financial year the bank provided the highest loan and focused on the agriculture sector. Development activities are the major role in rural development, the rural bank as provided loans towards the development activities in the year of 2015-16 to $3 \mathrm{~A} / \mathrm{c}$ holders of 1,10,000Rs, in the year of 2016-17 to the $1 \mathrm{~A} / \mathrm{c}$ holder of 3,50,000Rs. And in 2017-18 to $1 \mathrm{~A} / \mathrm{c}$ holder of 4,00,000Rs, provided. All three years focus on development activities in the year of 2017-18.

The rural bank another way to provide the loan to people for rural development, in case of the customer not having any assets like land, building, etc so, the bank has pledged the gold and provides the loans for short term period. In the analysis of gramina bank is provided a gold loan in the year of 2015-16 of 31 $\mathrm{A} / \mathrm{c}$ 's to $10,90,000 \mathrm{Rs}$, in the year of $2016-17$ as 30 $\mathrm{A} / \mathrm{c}$ 's to $12,10,000 \mathrm{Rs}$, and the year of 2017-18 was provided to $36 \mathrm{~A} / \mathrm{c}$ 's of $15,60,000 \mathrm{Rs}$. In all three years, the bank provided the gold loan of the 2017-18 financial year of the highest loan. Education is one of the main roles in rural development. In rural areas education is very necessary to rural development. In the educational sector loans provided only 2 years of 2015-16 and 2017-19 was 3,60,000Rs and $2,87,000 \mathrm{Rs}$ respectively. Self-help group also one of the important role in women empowerment and rural development. The bank has not focused on these sectors, but it is provided the loans off in 2015-16 financial year 1 group of account to 4,00,000Rs and 2016-17 was not providing any SHG loans, and in the year of 2017-18 was provided the 4 group of accounts was to 7,20,000Rs. Finally, the Pragathi Krishna Gramin Bank as the focused on the agricultural sectors and the loans provided this sector every year was providing a huge amount of agricultural sectors, and second priority for development activities.

Table 1: Gender and Age profile

\begin{tabular}{|c|c|c|c|c|c|c|}
\hline Villages & \multicolumn{2}{|c|}{ Basavanashivanakere } & \multicolumn{2}{c|}{ Byalahal } & \multicolumn{2}{c|}{ Bedarashivanakere } \\
\hline Gender & $\mathrm{Fq}$ & $\%$ & $\mathrm{Fq}$ & $\%$ & $\mathrm{Fq}$ & $\%$ \\
\hline Male & 05 & 50 & 07 & 70 & 07 & 70 \\
\hline Female & 05 & 50 & 03 & 30 & 03 & 30 \\
\hline Total & $\mathbf{1 0}$ & $\mathbf{1 0 0}$ & $\mathbf{1 0}$ & $\mathbf{1 0 0}$ & $\mathbf{1 0}$ & $\mathbf{1 0 0}$ \\
\hline Villages & \multicolumn{2}{|c|}{ Basavanashivanakere } & $\%$ & $\mathrm{Fq}$ & $\%$ & \multicolumn{2}{c|}{ Fq } & $\%$ \\
\hline Age & $\mathrm{Fq}$ & $\%$ Balahal & 50 & 03 & 30 \\
\hline $18-25$ & 01 & 10 & 05 & 20 & 05 & 50 \\
\hline $26-35$ & 05 & 50 & 02 & & \\
\hline
\end{tabular}


International Journal of Economics

\begin{tabular}{|c|c|c|c|c|c|c|}
\hline $36-45$ & 03 & 30 & 03 & 30 & 02 & 20 \\
\hline $46-65$ & 02 & 20 & 00 & 00 & 00 & 00 \\
\hline Total & $\mathbf{1 0}$ & $\mathbf{1 0 0}$ & $\mathbf{1 0}$ & $\mathbf{1 0 0}$ & $\mathbf{1 0}$ & $\mathbf{1 0 0}$ \\
\hline
\end{tabular}

Source: Field survey

\section{Gender}

The above question in the gender of the respondents in Basavanashivanakere as $50 \%$ of male and $50 \%$ of female. In Byalahal as $70 \%$ of male and $30 \%$ of female respondents and the Bedarashivankere as $70 \%$ of male and $30 \%$ of respondents in the responded survey.

\section{Age}

The age of respondents in Basavanashivanakere village the highest percentage of 26-35 years of $50 \%$ respondents and In a Byalahal is the highest percentage of $18-25$ years of $50 \%$ people has responded and in the Bedarashivanakere as the highest percentage of 50\% of 26-35years old people has respondents in my survey.

Table 2: Education and Occupational profile

\begin{tabular}{|c|c|c|c|c|c|c|}
\hline Villages & \multicolumn{2}{|c|}{ Basavanashivanakere } & \multicolumn{2}{|c|}{ Byalahal } & \multicolumn{2}{|c|}{ Bedarashivanakere } \\
\hline Occupation & $\mathbf{F q}$ & $\%$ & $\mathbf{F q}$ & $\%$ & $\mathbf{F q}$ & $\%$ \\
\hline Former & 02 & 20 & 02 & 20 & 02 & 20 \\
\hline Wage Laborer & 03 & 30 & 01 & 10 & 02 & 20 \\
\hline Skilled Worker & 02 & 20 & 01 & 10 & 01 & 10 \\
\hline Petty Traders & 01 & 10 & 01 & 10 & 02 & 20 \\
\hline Self Employment & 02 & 20 & 03 & 30 & 02 & 20 \\
\hline Entrepreneur & 00 & 00 & 02 & 20 & 01 & 10 \\
\hline Total & 10 & 100 & 10 & 100 & 10 & 100 \\
\hline Villages & \multicolumn{2}{|c|}{ Basavanashivanakere } & \multicolumn{2}{|c|}{ Byalahal } & \multicolumn{2}{|c|}{ Bedarashivanakere } \\
\hline Age & $\mathbf{F q}$ & $\%$ & $\mathbf{F q}$ & $\%$ & $\mathbf{F q}$ & $\%$ \\
\hline Illiterates & 05 & 50 & 01 & 10 & 00 & 00 \\
\hline Primary school & 00 & 00 & 01 & 10 & 01 & 10 \\
\hline SSLC & 03 & 30 & 00 & 00 & 03 & 30 \\
\hline $\mathrm{P} U \mathrm{C}$ & 01 & 10 & 03 & 30 & 04 & 40 \\
\hline UG & 01 & 10 & 05 & 50 & 02 & 20 \\
\hline Total & 10 & 100 & 10 & 100 & 10 & 100 \\
\hline
\end{tabular}

\section{Education}

Education of the respondents in three villages as the Basavanashivanakere have the highest percentage of the illiterate of $50 \%$ were responded, In Bedarashivanakere as the highest percentage of education in PUC of $40 \%$ of people responded, and in Byalahal have a $50 \%$ of undergraduate people. In analyzing the three villages in the Byalahalisadeveloped in the education field.

\section{Occupation}

Occupation of the respondents in three villages having different types of occupation, but in the
Basavanashivanakere village as having the highest percentage of people depending upon the agriculture, in this village $30 \%$ of people as former. In byalahal village the people having a self-employed of $30 \%$ of people, and in Bedarashivanakere as the equal to having a Former, Wage laborer, petty traders, selfemployed are equally having a $20 \%$ respectively.

\section{PKGB operation}

In the above statement of the table the respondents as responding about the name of the rural bank. In Basavanashivanakere as $100 \%$ of people in response to the Pragathi Krishna Gramin Bank, and Byalahal 
village also $100 \%$ of people responded to the Pragathi Krishna Gramin Bank, but in the Bedarashivanakere only $50 \%$ of people as given statement to the Pragathi Krishna Gramin Bank because the this village near have a another bank are available.

\section{Bank accounts}

The analyzed in three villages of the respondents are $100 \%$ of fully having a Bank accounts in a regional rural bank and almost the people having a different purpose like as, pension schemes, LPG subsidies, MGNRGA Scheme etc, of purpose utilizing their bank account.

Table 3: Factsheet of RRB and Rural Development

\begin{tabular}{|c|c|c|c|c|c|c|}
\hline Villages & \multicolumn{2}{|c|}{ Basavanashivanakere } & \multicolumn{2}{c|}{ Byalahal } & \multicolumn{2}{c|}{ Bedarashivanakere } \\
\hline Loan Received & $\mathbf{F q}$ & $\mathbf{\%}$ & $\mathbf{F q}$ & $\mathbf{\%}$ & $\mathbf{F q}$ & $\%$ \\
\hline Yes & 08 & 80 & 09 & 90 & 10 & 100 \\
\hline No & 02 & 20 & 01 & 10 & 00 & 000 \\
\hline Total & 10 & 100 & 10 & 100 & 10 & 100 \\
\hline \multicolumn{7}{|c|}{ Loan Profile of PKGB } \\
\hline Villages & Basavanashivanakere & \multicolumn{2}{|c|}{ Byalahal } & \multicolumn{2}{c|}{ Bedarashivanakere } \\
\hline Type of Loan & Fq & $\mathbf{\%}$ & $\mathbf{F q}$ & $\mathbf{\%}$ & $\mathbf{F q}$ & $\%$ \\
\hline Agriculture & 03 & 30 & 02 & 20 & 01 & 10 \\
\hline Educational & 00 & 00 & 00 & 00 & 00 & 00 \\
\hline Entrepreneurial & 00 & 00 & 01 & 10 & 03 & 30 \\
\hline Self-employment & 01 & 10 & 03 & 30 & 03 & 30 \\
\hline Housing & 05 & 50 & 02 & 20 & 02 & 20 \\
\hline Vehicle Loan & 01 & 10 & 02 & 20 & 01 & 10 \\
\hline Total & $\mathbf{1 0}$ & $\mathbf{1 0 0}$ & $\mathbf{1 0}$ & $\mathbf{1 0 0}$ & $\mathbf{1 0}$ & $\mathbf{1 0 0}$ \\
\hline
\end{tabular}

Source: Field Survey

\section{Bank Loans}

The analysis of three villages loan received from the rural bank, in Basavanashivanakere as $80 \%$ of people respondents received loans from the rural bank, in Byalahal village has received a loan of $90 \%$ of people received in Bank, and Bedarashivanakere, as received $100 \%$ of respondents, received in rural bank. The Bedarashivanakere is the highest loan amount received from the bank and the proper utilization of banking services.

\section{Sector-wise loan by PKGB}

The above statement of the table showing that respondents are received different types of loans from the bank. In Basavanashivanakere as the received a House loan highest $50 \%$ and $30 \%$ of the agricultural loan. In the Byalahal villages, the respondents are received a more $30 \%$ of Self employment and $20 \%$ of Agriculture, Housing, and Vehicle loan. And the Beadarashivanakere is received like 30\% of Entrepreneurial loan and Self employment loan. Three village people have received a different type of loan from a bank.

\section{Findings}

- Area of operation: The Pragathi Krishna Gramin Bank has a limited rural area of operation and it finances loan to different gross root economic activities in the rural area.

- Loan sanction: The village people are more than $80 \%$ of people received the loan from the RRB, in the different type of loans, like the agricultural loan, Self-employment loan, Housing loans, Vehicle, and entrepreneurial loans.

Characterization: The rural economy has highly characterized by agriculture and its allied activities wage based workers, selfemployment, and entrepreneurial activities, 
small and tiny farmers.

\section{Suggesions}

- Focused areas: The Bank needs to concentrates on women empowerment, selfemployment, and Entrepreneurial activities. The Bank needs to provide more loans and advances to education in rural areas.

- CRM practice: The Bank requires to maintain customer relationship management practices with the customers by improving in the Technology and Provide more customer services like ATM service, Gram Sevaka, Internet banking, etc.

- Entrepreneurial development: The majority of people have had only agricultural activity, so they need to do other economic activities likes Dairy husbandry, Poultry formation, Tailoring, and other rural development activities.

\section{Conclusion}

In the rural development, the regional rural bank is playing the vital role in the rural development activities through providing financial services to the rural socio-economical activities, such as agriculture, development activities, entrepreneurship development, educational loans services, and selfhelp group for women empowerment in the rural area. The regional rural bank is the main objective and function of the financing the rural sectors and provides ancillary banking service to the local people and supporting the upliftment of the quality life of people and development oriented towards the global village. In overall research of the regional rural banks and rural development, these two aspects as very closely depending on each other and the regional rural bank has the very helpful to the growth of rural development and our economic status of the country.

\section{Author Details}

\section{Mr.Harish Tigari}

Faculty Member, Department of Commerce, Davangere University, Shivagangotri, Karnataka, India

\section{Mr.M.G.Gaganadeepa}

PG Student, Department of Commerce, Davangere University, Shivagangotri, Karnataka, India

\section{References}

Biswa Swarup Misra, "The Performance of Regional Rural Banks (RRBs) in India: Has past anything to Suggest for Future?, Reserve Bank of India Occasional Papers," Vol. 27, Summer and Monsoon 2006.

Deepak Boora, Pawan Kumar, Shiv Ram Singh Jhajharia, "Role of Banking in Rural Area"s, IJLTEMAS, Vol III, Issue IA, 2014.

Gopal Lal Jain, Rural Development, Mangal Deep Publications, Jaipur, ISBN 81-7594-016-0, page no; 23-25.

http://cec.nic.in/wpresources/module/Commerce/ III_Year/199/econ\%201\%20transcript.pdf Indian Banking System, Regional Rural Bank in India(part-1)

https://en.wikipedia.org/wiki/Regional_Rural_Bank. "History of RRBs"

Kedar V Marulkar, "Role of Banks in Rural Industrialization, A research Paper to be presented at the National Conference on "Rural Industrialization" organized by Ajara Mahavidyalaya," Ajara on 5th and 6th February, 2010.

Manohar kacharu sanap, "Role and Responsibilities of RRBs for rural development of India," Chronicle of the Neville Wadia Institute of Management Studies and Research.

Moseley, Malcolm J. "Rural Development: Principles and practices" (1.pub1.ed.). London [u.a.]:SAGE.p.5.ISBN 978-0-76194766-0. 2003.

Subitha Devi, N., "Problems and Prospectus of Regional Rural Banks in India," International Journal of Managerial studies and research (IJMSR), Volume 2, April 2014. www. arcjournals.org

www.planningcommission.nic.in/plans/stateplan/ sdr_punjab/sdrpun_ch5.pdf 